\title{
DEMOCRACY IMPERILED: WAGES OF A FAILURE TO HEAL THE RACIAL DIVIDE
}

\author{
Lawrence D. Bobo \\ Department of African and African American Studies, Department of Sociology, \\ Harvard University
}

Unlike any previous era except the pre-Civil War years, many U.S. citizens find themselves worried about the durability of its democratic institutions. In a trenchantly argued book entitled How Democracies Die, political scientists Steven Levitsky and Daniel Ziblatt raise pointed questions about the health of American democracy in the Trump era. They begin with the observation that democracies do not typically fail via coups or military take-overs. Rather, democracies collapse from a rot within. This rot usually involves the inability of political elites-leaders of key political parties-to prevent extremist or anti-democratic figures from rising to positions of legitimate institutional power.

Although primarily students of political history and dynamics outside the U.S., Levitsky and Ziblatt see in Donald Trump a figure and set of circumstances that hew closely to conditions associated with dangerous threats to democratic systems. Trump's 2016 Presidential campaign clearly embodied each of the four indicators of a serious anti-democratic political contender. Trump openly suggested, first, that he might not accept the election results if he lost, based on dubious concerns over electoral fraud. Trump raised fundamental and openly demonizing challenges, secondly, to the legitimacy of his rival Hillary Clinton by calling for prosecution and imprisonment (including threatening to consider legal action against her if he won the election). During the 2016 campaign, third, Trump tolerated-if not encouraged-violence against protestors at a number of his political rallies. And lastly, Trump frequently mused about curtailing key civil liberty guarantees such as the necessity of a free press. Most disconcerting to Levitsky and Ziblatt is that Trump is the only serious contender for the presidency in the U.S. in the post World War II era to exhibit authoritarian tendencies in more than one of these domains (Nixon was a vigorous critic of the press as well): indeed, he embodied all four types of threats to democracy.

How does such a clear authoritarian rise to claim a major party nomination for President and then, in fact, win election to the Presidency? According to Levitsky and Ziblatt, elite safeguards that would have stymied or checked such a candidacy in the past, weaken or become compromised in the immediate political context. One critical

Du Bois Review, 16:1 (2019) 1-3.

(C) 2020 Hutchins Center for African and African American Research

doi:10.1017/S1742058X19000304 
element in the current U.S. political context is the historically extreme degree of partisan polarization and the extent to which that polarization is closely intertwined with the issues of race and ethnoracial diversity. One prominent reason why elites failed to prevent the rise to power of a strongly anti-democratic political actor and the reactionary political base that he curries, can be traced to America's continuing, deep, racial divide. In this case, however, Trump's successful political entrepreneurship amplified and gave newfound, more overt political expression to the racial divide (Bobo 2017). His ethnoracially divisive campaign-manifest in his vilification of Mexicans, calls for a Muslim ban, and coarse stereotyping of African Americans-reverberated with deep seated racial resentments in the current age of Laissez Faire Racism (Samson and Bobo 2014; Simmons and Bobo 2018).

In many respects, Trump's rise to power and the threat to democratic institutions that his brand of authoritarian rule embodies can be traced to the persistent failure to heal the racial divide in the U.S. Accordingly, the articles in this issue of the $D u$ Bois Review: Social Science Research on Race underscore the ongoing, deeply etched ways that race conditions social experience across multiple domains of life. Three of the pieces wrestle with how race powerfully conditions and inflects social processes. Sociologist Alex Manning takes up the question of class-based differences in child socialization practices, faulting previous research for not recognizing that race interacts with class in consequential ways. Legal scholar and philosopher, Christopher Lewis, takes up aspects of the question of whether Latinx should be seen as a heterogeneous ethnic grouping or a racial category. In particular, he argues that it is important to distinguish self-identity, social perception, and social categorization. Lewis emphasizes that from the vantage point of fighting discrimination and achieving social justice it may be more important to focus on perceived racial group membership and distinction than on self-declared identities. Sociologists Kiara W. Douds, Heather O'Connell and Jenifer Bratter examine the question of how White Americans perceive and explain racial inequality. They find no real difference in the perception among Whites regarding African Americans and Asian Americans that structural barriers impede minority achievement. However, Whites are a good deal more likely to see Blacks as lagging due to individual factors. That is, they rely on a more internal, dispositional account of Blacks as compared to Asian disadvantage. They interpret this pattern as reflecting the existence of a stronger set of symbolic boundaries Whites draw between themselves and Black as compared to Asians.

There are four pieces that grapple with how race is still in the foreground of political dynamics in the U.S. Political scientist Keneshia Grant traces how the African American Great Migration to urban and northern areas reshaped U.S. political party dynamics. Political scientist Marcus Lee examines the adoption of "Stand Your Ground" legislation in the state of Florida. While much of the overt discourse pivoted from concerns about reducing criminal justice system costs and the desire to insulate citizens who act to protect themselves from draining civil litigation or criminal vulnerability, there was really a deep racial discourse and project at work. The debate featured strongly racially coded discourse about combatting "drug dealers," "gang leaders," and presumed "cop killers.” Researchers Alecia McGregor, Laura Bogart, Molly HigginsBiddle, Dara Strolovitch, and Bisola Ojikutu consider civic participation among Black and LGBT voters. They question the common wisdom that members of lower status groups have lower political engagement and participation rates than higher status or dominant group members. In some contexts they find evidence for a "political hypervigilance" effect. Marginalized group members, perceiving a threat to their status, may actually become even more politically active than otherwise comparable dominant group peers. Political analyst Brandon Davis examines the dynamics of 
political competition in majority versus majority-minority electoral districts in the Alabama state legislature. Much political theory and research extols the benefits of real party competition. Davis's work suggest that majority minority districts are distinctly low on such competition.

Each of these pieces of research point to how race continues to shape individual, familial, and larger political dynamics. Where individuals and communities remain categorized, stigmatized and marginalized along lines of ethnoracial division a basis of profoundly differentiated social experiences persists. And as we've seen in the 2016 U.S. presidential election and its aftermath, the failure to heal these racial divides can trouble the larger and critically important success of the great experiment with democratic systems of government.

\section{REFERENCES}

Bobo, Lawrence D. (2017). Racism in Trump's America: Reflections on Culture, Sociology, and the 2016 U.S. Presidential Election, British fournal of Sociology, 68(S1): S85-S104.

Levitsky, Steven and Daniel Ziblatt (2018). How Democracies Die. Cambridge: Harvard University Press.

Samson, Frank L. and Lawrence D. Bobo (2014). Ethnoracial Attitudes and Social Inequality. In J. McLeod, M. Schwarzenegger, and E. Lawyer (Eds.), The Handbook of the Social Psychology of Inequality, pp. 515-545. New York: Springer-Verlag.

Simmons, Alicia D. and Lawrence D. Bobo (2018). Understanding "No Special Favors": A Quantitative and Qualitative Mapping of the Meaning of Responses to the Racial Resentment Scale. Du Bois Review: Social Science Research on Race, 15(2): 323-352. 